\title{
The Cultivation of Cross-cultural Communication Competence in Oral English Teaching Practice
}

\author{
Chunyan $\operatorname{Sun}^{1}$ \\ ${ }^{1}$ Foreign Language Teaching Department, Inner Mongolia University for the Nationalities, Tongliao, 028000, \\ China \\ Correspondance: Chunyan Sun, Foreign Language Teaching Department, Inner Mongolia University for the \\ Nationalities, Tongliao, 028000, China. E-mail: tomshilizhi@163.com
}

\author{
Received: September 30, 2015 Accepted: October 30, 2015 Online Published: November 2, 2015 \\ doi:10.5539/elt.v8n12p7 URL: http://dx.doi.org/10.5539/elt.v8n12p7
}

\begin{abstract}
This paper analyzes the main problems and difficulties in current college English oral English teaching practice, illustrates the relationship between oral English teaching and cross-cultural communication competence. On the one hand, cross-cultural communication plays an essential role in oral English teaching; besides, oral English teaching promotes cross-cultural communication competence. Our oral English teaching concept should be consistent with that of the world. We should lay equal stress on cross-cultural communication competence and oral English teaching for the purpose of improving the students' cross-cultural oral communication ability.
\end{abstract}

Keywords: oral English teaching, cross-cultural communication competence, language culture

\section{Introduction}

Language communicative ability is of great importance in the course of English teaching. Nowadays, more and more scholars both at home and abroad have come to realize the essence of language, and the cultivation of communicative competence being the key to language learning is well accepted. Guided by foreign language teaching theories, the main content of college English includes English language knowledge, application skills, cross-cultural communication and learning strategies. It is somehow a teaching system which integrates a variety of teaching mode and teaching methods. Therefore, college oral English teaching is not merely the input of language knowledge, but also refers to a combination between the language and its culture.

\section{The Problems Confronting College English Teaching}

The teaching program says: "The teaching objective is to improve college students' ability of English listening, speaking, reading, writing and translating." However, the teaching objective fails to meet its aim somehow for a variety of reasons. Our foreign language teaching here lays particular stress on language forms including pronunciation, grammar, the meanings of the word, etc. In fact, we have trained a lot of students who are capable of grammar teaching, but they do not have the real communicative ability, which makes our language learning meaningless. Let's analyze what causes this phenomenon. According to the survey, a large number of teachers of English cannot speak standard Chinese, let alone English, because the strong local accent makes it difficult to speak idiomatic English. Unfortunately, most of the teachers who have such kind of problems don't realize it. If the students in class just follow suit, results can be well imagined. To solve this problem, the teachers should promote their specialized quality as soon as possible by correcting their pronunciation of Chinese and English. In northern China, a lot of teachers have difficulty in pronouncing ' $z$ ' and ' $z h$ ', 'c' and 'ch', 's' and 'sh' in Chinese. Besides, some teachers usually neglect the sound $/ \theta /$, and they never bite their tongue when pronouncing this sound. So you can always hear teachers say 'sank you' instead of 'thank you'. To solve this problem, the teachers should make an effort to improve themselves and set a good example for the students, because someone once said "We teach some by what we say. We teach more by what we do. But we teach most by what we are." If the teachers have a strong desire to improve themselves, the students will benefit a lot for sure. What's more, the reason for this problem is also related to the students themselves. Unlike the time when they were learning their mother tongue, the students are afraid of making mistakes when they speak English, which is obviously a big barrier for them to learn a foreign language, especially for the students who do not have a very good language environment. Last but not least, no matter what levels the students belong to, their main task in the oral English class is still related to the sentence pattern drills, so after class the students still focus on reading as well as 
writing. So it is urgent to change the teaching methods in the course of oral English teaching.

\section{The Relationship between Cross-Cultural Communication and Oral English Teaching}

"Language is a part of culture, culture is also a part of language. It is difficult to separate both of them." This better explains the close relationship between culture and language.

College English Course Teaching Requirements, issued by Department of Higher Education, Ministry of Education of P. R. China, points out that college English teaching is based on English language knowledge, application skills, cross-cultural communication as well as learning strategies, aiming to promote the students' comprehensive proficiency in applying English, especially their listening and speaking ability in the real situation. Meanwhile, make sure that they can communicate efficiently both orally and literally in English in their future career and social communications.

Krashen points out, "The basic function of the classroom is to provide students with the chance of knowledge input and place to which they get no access elsewhere." At the same time, teachers should offer students the opportunities to practice the language in the situation which the native speaker may encounter in their daily life and solve the culture conflicts along the way with the students.

Oral English class is a place where students can get access to the opportunity to improve their verbal and nonverbal communication skills. Cross-cultural communication is the main part of it. The ultimate goal of language teaching is to communicate with others freely and improve the overall cultural accomplishments.

\section{The Main Reasons of Cross-Cultural Communication Failure}

Lack of deep understanding toward the culture behind the language. For a long time, we put emphasis on systematic teaching of the language, that is, language knowledge, pronunciation, grammar and vocabulary in the process of oral English teaching. We just ignore the input the relevant cultures behind the language which is equally important. As a result, the students have no idea of the cultures and values of the English-speaking countries. There is no doubt that they will make mistakes and even can not be understood while communicating with the native speakers.

Lack of the English-speaking environment. In the traditional oral English class, teachers play a dominant role and students are merely passive listeners, just simply memorize the sentence patterns one by one. Undoubtedly, this kind of practice lacks of communicative efficiency. Finally, the students are thus reduced to a passive position. Although most students have memorized a lot of fixed expression forms and idioms, they still make many mistakes when it comes to using them in the daily communication with the native speakers, because they do not master the inherent meanings of them. Besides, college students lack the opportunities to apply what they have learned in class to the real situations when English is being spoken, and they even do not have the courage to open their mouth to speak English.

Lack of understanding the style of language. The choice of language form is constrained by a few factors. The relationship between the two sides; the content of the topic discussion, background and even ways of communication will influence the forms of conversation; traditionally, the students pay much more attention to memorizing grammar rules by rote learning and blurt out sentences without the real language context. In this way, the students can't use the language freely. In verbal communication, the students usually neglect the rank of the person he is talking to, the environment of the conversation and the wrong style of language leads to the failure of intercultural communication.

\section{How to Improve Students' Cross-Cultural Competence in Oral English Teaching}

According to the characteristic of oral English, oral English teaching should be based on the relative pedagogy, psychology and linguistic theory. Oral English teaching involves multiple interactions in terms of teaching aim, teaching contents, teaching strategies, and evaluation methods. Student-oriented, network-driving, input-based, real language environment, interaction from all dimensions, all of these are the necessary factors in improving the students' intercultural communication skills.

\subsection{Improving Teachers' Own Qualities}

As the organizer of the oral English class, teachers should set good examples for the students. Only by possessing certain knowledge about intercultural communication, can teachers handle the class with high proficiency. To achieve this goal, teachers should have a better language foundation and a strong intercultural communication competence. Therefore, for one thing, we can invite some famous scholars and experts to give lectures about inter-culture to the teachers in the school, so as to improve the teachers' overall quality and intercultural speculation awareness. For another, we can send our teachers abroad as visiting scholars, Chinese 
volunteers, etc. In this way, they can experience the foreign cultures in person and accumulate the necessary teaching materials. And then, our students will benefit a lot from it.

\subsection{Enhancing Listening Practice, Increasing Language Input and Storage}

The main aim of enhancing the students' transfer competence of language knowledge is to help them to acquire knowledge, information by means of reading as well as listening, and recombine what they have heard through internalization, then it is possible for them to output the language. So the whole communication process is completed. As we know, language input is the essential condition to language output. Listening is the first and most important step in learning a foreign language and it is the important method of inputting information. For college students, long exposure to English will be good for their language sense and right expressions of their own thoughts. Oral English study should start with lots of listening practice. The more you listen, the more exactly you know under what kind of circumstances you can say it, the more you want to express yourself in English when you encounter the situation. There is no doubt that verbal communication is the inevitable result of lots of listening practice.

\subsection{Carrying Out Multimedia Integrated Teaching Model}

Multimedia teaching is the combination of the three-visual, audio, language. The students can experience what they have learned through this multisensory training as if they were in the real native language environment which is necessary for any language learners. Specific new media introductions are as follows, such as English Liu Li Shuo learning software. The lessons on it are very organized. One module has ten different lessons. A module will focus on one topic, such as business, college life or travel. And each module consists of ten related dialogues, which allows you to learn English when it's convenient for you. It offers two different ways to learn: Practice and Quiz. In Practice, you can study the lesson at your own pace, while in Quiz, you can test what you have learned in the same lesson. If you study hard, it is possible to get on the leaderboard. There are a lot of different learning materials for different learners of different levels. You are sure to find what you need.

Lizhi FM is another useful learning software. This learning tool makes it possible for anyone who wants to be News Anchor. The students can record their favorite article with the beautiful background music they like and post it onto the new media platform, like Wechat, QQ, Blog etc to show off. In this way, students can make his voice be heard by other people, and also others can share it, comment it, and even have an online communication. Of course, the students can subscribe other people's channel and and enjoy it anytime. What's more, the English Dubbing Show is a fantastic software for the English learners. You can realize your dream of becoming a famous voiceover to the movie you love. You can also invite other people to cooperate with you to finish the work. Once finished, you will get the sense of achievement which can drive you to practice oral English with confidence and happiness. All in all, college students can improve their oral expression ability and communicate with the native speakers in decent language through different types of language training.

\subsection{Cultivating English Thinking Habit}

In oral English teaching, teachers are supposed to help their students form the good habit of communicating with others orally and think in English at the same time. Thinking in English means you have to understand, judge and express yourself in English instead of Chinese. That is to say, you have to exclude the interference of your mother tongue. How can you think in English naturally? I believe the best way is to practice just as what a football player does every day. During the practice, the football player will pass the ball to his teammates over and over again, so he won't have to think about the action — passing the ball in the game, he will just do it by instinct.

You can train yourself to think in English in a series of steps. The first step is to think of the simple words that you often use in daily life, like book, shoes or tree. For example, whenever you see a "book", you should think of it in English instead of in your mother language. Second, after you have learned to think of several words in English, you should move on to the next step-thinking in sentences. Listening and repeating is a very effective way to learn a foreign language. At first, just listen and don't care too much about whether you have fully understood what you're hearing. Try to repeat whatever you hear in English. The more you listen, the more you acquire. After you reach a higher level, start having conversations with yourself in English, which will lead you to think in English.

While the people who don't have this kind of training experience might tend to translate what they have heard into their mother language and then store them in their memories. When it is time to output them, they would try their best to search for the corresponding expressions in their mother language and translate them into English. This is inevitably leads to the interference of one's mother language. This is also the origin of Chinglish. 
Now, let's look at a few examples about Chinglish. For example, “我非常喜欢英语。” should be translated into "I like English very much."While, for most of the Chinese English learners, they are more likely to say, "I very like English."Besides, when it comes to the foreigners “黄头发”, according to their mother language habits, they would prefer to say "yellow hair". Actually, in the west there is no such expression as "yellow hair", people would like to say "blonde hair" instead. These translation methods lead to misunderstandings, even barriers in our communication with westerners. In the process of learning English, we should encourage students to listen to the real English and cultivate the habit of understanding what they hear in English and store them in their mind. At the same time, the teacher should help the students to overcome the interference of their mother language and express themselves in English directly and freely. The students acquired the real oral English communicative competence through a series of initiative and active conceptual work, understanding and expressing ideas, input and output the messages.

\subsection{Enriching Culture Teaching Through Extracurricular Activities}

In view of the deficiency in our foreign language teaching in college in terms of teaching time, teaching method, teaching process, etc., we can barely undertake the task of cultivating the students' intercultural communication awareness and ability. Therefore, the abundant extracurricular activities play a key role in awaking the students' culture consciousness. In order to make up the deficiency of classroom teaching, students should be encouraged to make full use of their spare time and grasp the opportunities offered by the teachers to know more about English culture and cultivate their communicative competence. The school can organize some culture forums for the students and invite some teachers who have the overseas experiences or foreign teachers to introduce something about the culture and convention abroad that the students are eager to know. Also, we can hold the Foreign Movie Appreciation which will offer the students the opportunity to learn more about the study, life, love and work of the people in the west, to "experience" the people's lives indirectly. A wealth of extracurricular activities such as English Quiz Show, English Speaking Contest, English Imitating Contest or English Debating Contest can be organized on a regular basis, through which we can fully combine the language, culture study and after-school life.

\section{Conclusion}

In a word, in the process of foreign language teaching, English teachers should give up their old-fashioned teaching concept, try some new teaching methods and new strategies, and social and cultural knowledge teaching should be carried out throughout the teaching of language knowledge and skills. In addition, the cultivation of intercultural communication competence doesn't just focus on culture and neglect language. It is also not a culture-centered thing. It is a kind of method of teaching language from the culture point of view. As an organic component of teaching, the cultivation of intercultural communication competence has a long way to go. College English teachers should cultivate the students' ability of acquiring the language knowledge as well as their ability of social communication. This is a very important task for English language teaching.

\section{References}

Chen, S. (1997). The Relationship between culture and foreign language teaching. Foreign Language Teaching Abroad.

Hu, W. (1998). Beyond the Cultural Barrier. Beijing: Foreign Language and Foreign Language Teaching Press.

Liu, C. (2003). The Importance of Extracurricular Learning Activities In Oral English Teaching in University. Journal of Ningbo University, 2.

Liu, H., \&Yu, W. (1998). Communication Skills and Oral English Teaching. Foreign Language and Foreign Language Teaching Press.

Lai, Z. (1998). On Discussion the Culture Barrier and Foreign Teaching During Intercultural Communicatio. Journal of Longyan Teachers.

\section{Copyrights}

Copyright for this article is retained by the author(s), with first publication rights granted to the journal.

This is an open-access article distributed under the terms and conditions of the Creative Commons Attribution license (http://creativecommons.org/licenses/by/3.0/). 